\title{
Club Dead, Not Club Med: Staging Death in Contemporary Tana Toraja (Indonesia)
}

Kathleen M. Adams

Loyola University Chicago, kadams@luc.edu

Follow this and additional works at: https://ecommons.luc.edu/anthropology_facpubs

Part of the Anthropology Commons

\section{Recommended Citation}

Adams, K. (1993). "Club Dead, Not Club Med: Staging Death in Contemporary Tana Toraja (Indonesia)." Southeast Asian Journal of Social Science (now Asian Journal of Social Science), 21(2): 62-72. Available at http://dx.doi.org/10.1163/030382493X00116

This Article is brought to you for free and open access by the Faculty Publications and Other Works by Department at Loyola eCommons. It has been accepted for inclusion in Anthropology: Faculty Publications and Other Works by an authorized administrator of Loyola eCommons. For more information, please contact ecommons@luc.edu. cc) (i) $\Theta$

This work is licensed under a Creative Commons Attribution-Noncommercial-No Derivative Works 3.0 License. (c) Brill, 2000. 


\title{
Club Dead, Not Club Med: Staging Death in Contemporary Tana Toraja (Indonesia)
}

\author{
Kathleen M. Adams \\ Department of Sociology and Anthropology, Loyola University of Chicago
}

\section{Introduction}

In his classic work Political Systems of Highland Burma (1954), Edmund Leach illustrated how aspects of Kachin social structure (cf. kinship systems) are constructed in interaction with neighbouring groups. Since Leach laid out his dynamic conception of highland Burmese social systems, subsequent generations of Southeast Asianists have begun to explore the ways in which discourses between groups and institutions have shaped socio-cultural features associated with those groups. For instance, in his discussion of religious rationalization in Bali, Clifford Geertz (1964) suggests that transformations of Balinese religious institutions in the 1950s were in part a product of Balinese attempts to wrestle with their place in the new Muslim-dominated Indonesian nation. More recently, Jane Atkinson (1983) has demonstrated how the construction of the central Sulawesi Wana religion is anchored in a discourse with both world religions and nationalist Indonesian civil religion.

Likewise, a number of the essays in Kipp and Rodgers' volume on Indonesian religions in transition (1987) are concerned with the reformulation of "indigenous" religions as they engage in dialogue with the Indonesian government and world religions (cf. Hoskins, 1987; Tsing, 1987). This essay is broadly concerned with this theme of discourse and religious practices among the Sa'dan Toraja people of upland Sulawesi.

Specifically, I wish to explore some of the ways in which the Torajan mortuary complex of the 1980s and 1990s has been reconceptualized as Torajans' encounters with the wider world intensify. Outward migration (merantau) to urban centres in Indonesia, increased familiarity with the bureaucratic organization of the Indonesian government and the Church, the spread of television, and the ever-growing presence of tourists and anthropologists in Tana Toraja Regency have all fostered Torajans' rethinking of their "traditional" funeral rituals. In short, this article examines how the national media, the travel industry, and Indonesian civil religion have begun to reshape local ideas about what constitutes a "successful" Torajan funeral. As I will suggest, in the 1990s the Torajan funeral is a product of this discourse with the nation and the West.

\section{The ethnographic setting}

In the anthropological and touristic literature on Southeast Asia, probably no other group is as celebrated for its mortuary rituals as the Sa'dan Toraja of upland Sulawesi. 
Numbering approximately 350,000 , the Sa'dan Toraja are a minority group in the multi-ethnic archipelago nation of Indonesia. They are marginalized not only by their relatively small numbers, but by geography and religion, as well. Predominantly wetrice agriculturalists, the Sa'dan Toraja speak both Tae' Toraja and the national language of Bahasa Indonesia. Torajans traditionally resided in scattered mountain-top hamlets, maintaining social ties through an elaborate system of ritual exchanges, in which the mortuary complex played a key role (Nooy-Palm, 1979, 1986; Koubi, 1982). These Torajans referred to their system of ritual practices as Aluk or Aluk to Dolo (Ways of the Ancestors).

The Torajan social world is hierarchically organized on the basis of age, descent, wealth and occupation. Traditionally there were essentially three social strata: the aristocracy, commoners and slaves. Rank was determined by birth, although economic aptitude or failure allowed for some degree of social mobility. Both death and life rituals (rambu solo' and rambu tuka', respectively) were important arenas for displaying one's status.

The Dutch colonial incursion into upland Sulawesi in 1906 and the subsequent arrival of Calvinist missionaries in the 1910s heralded changes for the Torajans. For the first time ever, Torajans were united under a single political authority. As the Dutch relocated isolated mountain-top villages to the valleys (where they could be more easily monitored) and as missionaries mounted their proselytizing activities, Torajans began to develop new notions of their identity and place in the world. As Terance Bigalke documents, it was during this period of upheaval that Torajan ethnic identity first began to coalesce (Bigalke, 1981). Today, Christianity is an important aspect of Torajan identity - over 80 per cent of Torajans have converted to Christianity, with only 11 per cent remaining faithful to Aluk to Dolo (Kantor Statistik, 1983).

Following Indonesian independence, Muslim rebellions in South Sulawesi deterred outsiders from visiting the Toraja highlands during the 1950s and 1960s. By the late 1960s, however, the first anthropologists began to arrive and embark on the documentation of Torajan ritual, religion and politics (cf. Crystal, 1970, 1974; NooyPalm, 1979). On the heels of these anthropologists came European and American tourists, encouraged both by the Indonesian government (which in 1974 began to promote Outer Island tourist destinations) and by the European airing of a television documentary featuring a pageantry-filled Torajan funeral (Crystal, 1977; Spillane, 1987). The touristic marketing of Tana Toraja was an immense success. Whereas in 1973 only 422 tourists ventured to the Toraja highlands, by 1990 approximately 211,000 domestic and foreign tourists were visiting the region annually (Tana Toraja Kantor Parawista records). Today, tourists interested in visiting what some jestfully term "Club Dead, not Club Med" are very much a part of the Torajan landscape (cf. Groer, 1991).

\section{An early glimpse of the Torajan mortuary complex}

Not surprisingly, we find the initial accounts of Torajan death rituals in the writings of the early Dutch missionaries. J. Belksma, an emissary of the Dutch Reformed Alliance, first described the array of Torajan funerals, from the most abbreviated types of funeral for slaves to the lengthy and elaborate mortuary rites for the wealthy 
elite (Belksma, 1922, 1923). ${ }^{1}$ It was not until several decades later that Harry Wilcox introduced the English-speaking world to the Toraja and their "superior type of funeral" (Wilcox, 1949). Wilcox, a war-weary soldier, offered a sensitive description of Torajans in a popular account of his six-month stay in this mountain "paradise" at the end of World War II. Pronouncing death feasts "the supreme occasions of Torajan cultural life" (Wilcox, 1949:22), Wilcox opened his chapter on Torajan funerals with this declaration:

Had I kept an engagement book during my time in La'bo [a Torajan village in the Ke'su region] most of the dates noted in it would have been funerals. The most frequent occasions of entertainment, song and dance in the Toraja country are the death feasts ... It is difficult to believe that there remains in existence anywhere in the world a pagan festival so exciting, so colourful or so impressive as a great Torajan tomate [Wilcox's gloss for funerall. To take part in one is to voyage for a few brilliant hours far back along the track down which our ancestors made their way from the silver mists of the antique world. An adventure. (Wilcox, 1949:67)

Wilcox's superlative-laden portrayal of Torajan death rituals foreshadows both the tone and central themes of the touristic literature that began to emerge in the late 1970s and 1980s (see Adams, 1984, 1988). Superlatives aside, however, Wilcox provides us with one of the few detailed accounts of Torajan funerals of this period, from preparation to culmination. In particular, he offers a wealth of information about the funeral ritual for his friend Palinggi's father. Wilcox describes how, as the local males erected bamboo guest pavilions and females baked mounds of biscuits and cakes for the guests, he helped type the funeral invitations and assisted Palinggi in retrieving his frequently mislaid file concerning the funeral plans. At one point, Wilcox even shares with us the contents of this sheaf:

papers with names and numbers of the various ceremonial delegations and their agreed times of arrival and contributions, lists of bulls given outright for sacrifice or lent only for fighting, lists of borrowed crockery and finery for the dead man's effigy ... (Wilcox 1949:76).

Not surprisingly such lists are still compiled today, although they are much more intricate.

Wilcox goes on to chronicle the five-day long ritual itself, describing the thrill of the dead person's arrival on the feast field, and the water buffalo fights and slaughtering that punctuated the ritual activity. As he notes, however, these events were the only occasions of "sustained and titanic excitement". In his words:

In the days that followed there were many ... hours of tranced indolence ... [Remember] there are many days and nights to a death feast and the more clamorous thrills occupy at most an hour or two. The main activities are the arrival and reception of ceremonial delegations by day and dancing by night. (Wilcox, 1949:77-78).

Wilcox's portrayal of a Torajan funeral on the eve of Indonesian independence both resonates and contrasts with my own experience while conducting two years of field research in Tana Toraja Regency in 1984-1985 and in 1987 and 1989. In the following section I will describe a 1987 Torajan funeral ${ }^{2}$ with the aim of teasing out 
some of the ways in which Torajans are reconceptualizing their mortuary rites as their encounters with the wider world intensify.

\section{$\mathrm{Ne}^{\prime} K^{\prime} \mathrm{te}^{\prime}$ s 1987 funeral}

In January of 1987, tourists disembarking from their jets in the capital of south Sulawesi were welcomed with a mimeographed announcement of an elaborate, pageantry-filled funeral ceremony to be held in the Toraja highlands for the late $\mathrm{Ne}^{\prime}$ Ke'te. ${ }^{3}$ Using a smattering of anthropological terminology, the pamphlet outlined the social functions of Torajan funeral rituals, made reference to a Torajan origin myth and presented a schedule of events for the ten-day ritual. Articles in Indonesian newspapers, television spokesmen, hoteliers and travel agents all boasted that this was the first Torajan funeral ceremony that would adhere to a definite time schedule - this time no tourists would be disappointed by the last-minute postponements that were typical of Torajan rituals.

$\mathrm{Ne}^{\prime} \mathrm{Ke}^{\prime} \mathrm{te}^{\prime}$ himself had been a prominent local figure: in addition to his role as knowledgeable elder, he had once served as a government representative (DPR) and was an ex-secretary of the Protestant Toraja Church. His funeral promised to be an important event for the entire Torajan community. Rumours had it that four cabinet ministers as well as several governors and a foreign ambassador were expected to attend his funeral - all told, some 30,000 guests were anticipated. 4

Along with the bus loads of Indonesian and foreign tourists, I returned to Tana Toraja for $\mathrm{Ne}^{\prime} \mathrm{Ke}^{\prime} \mathrm{te}^{\prime}$ s funeral. I had lived for two years with $\mathrm{Ne}^{\prime} \mathrm{Ke}^{\prime} \mathrm{te}^{\prime}$ and his family during my original fieldwork and my apprehension about juggling my roles as researcher and mourner was particularly pronounced on this journey. I arrived in $\mathrm{Ne}^{\prime}$ Ke'te's village to find that its transformation was already well underway. Dozens of two-story bamboo guest pavilions had been erected around the perimeter of the ritual field. Men were busy painting the facades of the pavilions with motifs drawn from carvings on traditional houses. At the entrance to the village was a large and elaborate bamboo structure with a particularly exceptional view of funeral site: this was designated the V.I.P. guest pavilion. From a borrowed generator ran a loudspeaker system and, for the first time, I saw the village illuminated with electric lights.

I was greeted by $\mathrm{Ne}^{\prime} \mathrm{Ke}^{\prime}$ te's sobbing widow, his siblings and children. After taking me to see $\mathrm{Ne}^{\prime} \mathrm{Ke}^{\prime}$ te's body, which was housed in the tongkonan (kindred house), the oldest son wasted no time in presenting me with a mimeographed bundle which revealed the extent to which the funeral planning had become an involved bureaucratic process. Emulating Indonesian government and church organization, $\mathrm{Ne}^{\prime} \mathrm{Ke}^{\prime}$ te's family had designated a funeral secretary and drawn up this multi-paged list of some two dozen funeral committees. Committees included an entertainment committee, a documentation committee, a clean water committee, and a V.I.P. guest reception committee. As I discovered in conversations over the next few days, individuals who had previously toiled in a variety of arenas at funerals (depending on their kinship ties to the deceased, rank, wealth and inclination) came to conceptualize their role at $\mathrm{Ne}^{\prime} \mathrm{Ke}^{\prime} \mathrm{te}^{\prime} \mathrm{s}$ funeral in terms of the committees on which they served. At this funeral, kinfolk encountering each other for the first time began their conversations by inquiring as to what committees they were serving on. In contrast to the death 
ritual witnessed by Harry Wilcox, the organization of this 1987 funeral was not fluid but carefully structured in a way that reflected Torajans' growing discourse with the bureaucratic worlds of organized religion and national politics. ${ }^{5}$

Like Wilcox, I was also drawn into the work of the funeral, albeit in a more formal manner. The family had assigned me to two committees, the V.I.P. guest reception committee and the funeral documentation committee (family members chuckled that they had strategically planned to harness my anthropological skills). I have discussed elsewhere (Adams, in press) how my assignments on the V.I.P. guest reception committee involved strategically glossing controversial aspects of the funeral rites for visiting dignitaries (e.g. down-playing sensitive issues of rank and highlighting the "positive" effects of large-scale water-buffalo sacrifice). My assigned tasks evidence Torajans' attempts to recast their mortuary imagery in ways more acceptable to outsiders. Here I wish to focus attention on the funeral documentation committee.

The documentation committee consisted of myself, two reporters who were related to the deceased and a video expert. Whereas in the past raising a megalith served to memorialize the deceased, today the rites of death must be recorded for posterity in media form. For the elite, photographs alone no longer suffice. In an era where television is increasingly accessible in the highlands, and tourists traipse through Torajan villages toting camrecorders, video recordings of family funerals are increasingly de rigueur. That few of these families own VCRs is immaterial. $\mathrm{Ne}^{\prime}$ Ke'te's widow does not own a VCR but today her shelf displays a copy of the video of her husband's funeral, as well as several articles written by members of the documentation committee about the ritual. In short, in contemporary Tana Toraja a key marker of the importance of a funeral is its being documented on video or, at the very least, recorded on audio tape.

Moreover, it is not only the shift from orality to literacy, but also discourse with anthropologists recording life histories, and encounters with biographies in school that have all prompted more and more aristocratic Torajans to distribute booklets chronicling the life of the deceased at their funeral rituals (cf. Anon., 1985; 1987). Whereas in the past, the ma'badong chant for the deceased (cf. van der Veen, 1966) fulfilled this function at funeral rituals, today this alone is not the mark of a successful funeral. At $\mathrm{Ne}^{\prime} \mathrm{Ke}^{\prime}$ te's funeral, a specially-made 20 page booklet was distributed to all Indonesian-speaking guests. Included in this booklet were $\mathrm{Ne}^{\prime} \mathrm{Ke}^{\prime} \mathrm{te}^{\prime} \mathrm{s}$ life history, spiritual songs, a partial committee list, a poetic portrait of $\mathrm{Ne}^{\prime} \mathrm{Ke}$ 'te, and a programme of events. As a member of the Documentation Committee, I was asked to translate $\mathrm{Ne}^{\prime} \mathrm{Ke}^{\prime} \mathrm{te}^{\prime} \mathrm{s}$ biography into English for the foreign guests. The translation was distributed to all of the foreigners who, with varying degrees of success, were corralled into the specially-constructed tourist pavillion.

Exposure to mass media has also ushered in a new emphasis on the importance of continuous entertainment. Unlike Wicox's 1949 mortuary ritual at which guests' entertainment was not a priority (their attention was expected to ebb and flow), in current-day Tana Toraja elite sponsors of funerals are increasingly approaching the ritual as a spectacle requiring a faster-paced lineal programme of entertainment. The very existence of an entertainment committee and an emcee at $\mathrm{Ne}^{\prime} \mathrm{Ke}^{\prime} \mathrm{te}^{\prime}$ s funeral attests to this phenomenon. The emcee's duties were to usher along the programme of events, occassionally offering narration for those unfamiliar with Torajan customs. 
The entertainment committee arranged the performances of various local dance troupes and saw to it that the groups on display wore co-ordinated, aestheticallyappealing outfits. Such attention to costume was not only directed at the singers and dancers: male family members all received matching dress shirts batiked with black and white Torajan designs as their funeral "uniforms." 6 The very concept of having aesthetically co-ordinated "uniforms" appears to be a relatively recent phenomena, not at all mentioned in the early accounts of Torajan funerals. Although concrete evidence is unavailable, I suspect that this practice has developed out of Torajans' introduction to national military and school uniforms. Exposure to televised ethnic variety shows featuring performing groups from different regions of Indonesia clothed in matching theatrical versions of their ethnic garb appear to be influencing Torajan ideas about funeral attire and choreography, as well. Certainly, the Torajans I lived with paid close attention to these television ethnic variety shows, occasionally commenting on the shimmering textiles used to "modernize" ethnic costumes. The emcee's performance at $\mathrm{Ne}^{\prime} \mathrm{Ke}^{\prime} \mathrm{te}$ 's funeral also reflected an awareness of this genre of TV variety show. This was particularly apparent in his steady narration of funeral rites as well as in his devotion to keeping up the flow of events. Just as a variety show is never without a narrator, $\mathrm{Ne}^{\prime} \mathrm{Ke}^{\prime}$ te's funeral was never without an emcee: when the official emcee took breaks, younger males filled in for him. Whereas in the past there was no such thing as a funeral "emcee", 7 today it has become a distinctive and politically-important role at large-scale Torajan death ceremonies.

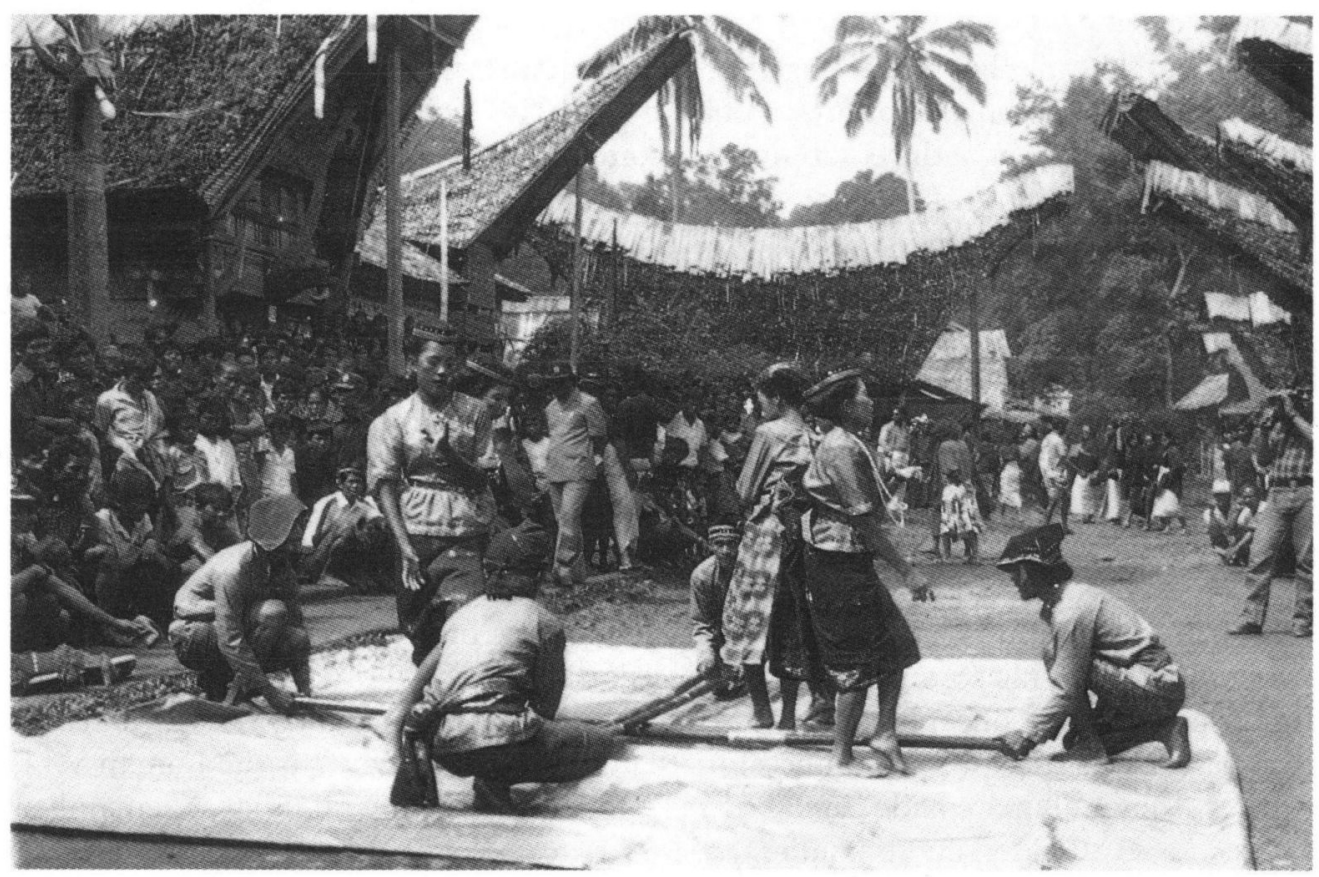

Plate 1. Dancers from central Sulawesi perform for the other guests and Ne Ke'te's family. (Note in the far right corner the member of the documentation committee videoing this performance.) 


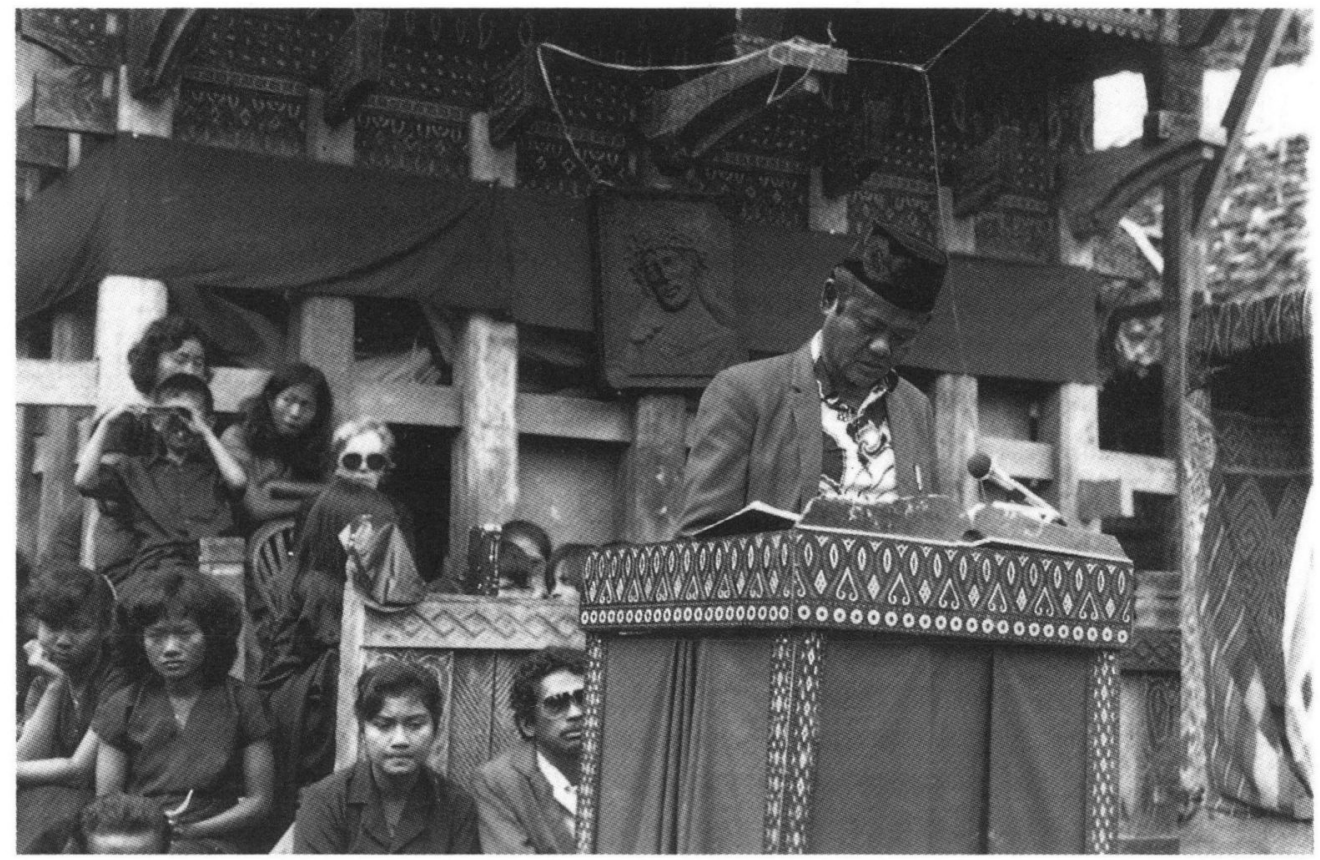

Plate 2. The emcee offers one of several closing prayers on the final day of $\mathrm{Ne}^{\prime} \mathrm{Ke}^{\prime} \mathrm{te}$ 's funeral. His voice is amplified by microphone and recorded on cassette. In the background the youngest son of the deceased (on the far left) takes snapshots of the event.

At this and other recent large-scale Torajan funeral rituals, keeping the audience satisfied has become an important objective. At $\mathrm{Ne}^{\prime} \mathrm{Ke}^{\prime} \mathrm{te}^{\prime} \mathrm{s}$ ritual, not only did the emcee and members of the entertainment committee admonish speakers to limit their speeches to ten minutes "so that guests would not be bored", but various rites were juggled or delayed for the sake of the V.I.P. audience. For instance, on the seventh day of the ritual (known as ma' palao), in the early afternoon the family had scheduled an elaborate procession to transport the corpse to a stately tower (lakkian) situated at the edge of the ritual field. From this tower, the deceased and several of the immediate family members were to watch over the remainder of the funeral proceedings. At the last minute the funeral hosts received word that the V.I.P. guests were going to be an hour late in arriving. Several of the family leaders gathered and quickly decided to delay the procession until they arrived. When some participants complained that delaying this rite would constitute a transgression of adat, one member of the entertainment committee rebutted that "the success of a funeral depends on guest reception". Both his comment and the decision to delay the procession reflect a shift in some Torajans' conceptions of the primary audience for mortuary rites. Whereas in the past it was the spirits and ancestors that held sway, today it is the human V.I.P. guests. Toby Volkman made similar observations at a 1985 funeral ritual at Pemanikan, which I also attended and documented. She writes,

At Pemanikan, the linear structure of events was striking. Both simultaneity of actions and diffuse time disappeared, replaced by a totally regulated one-track 


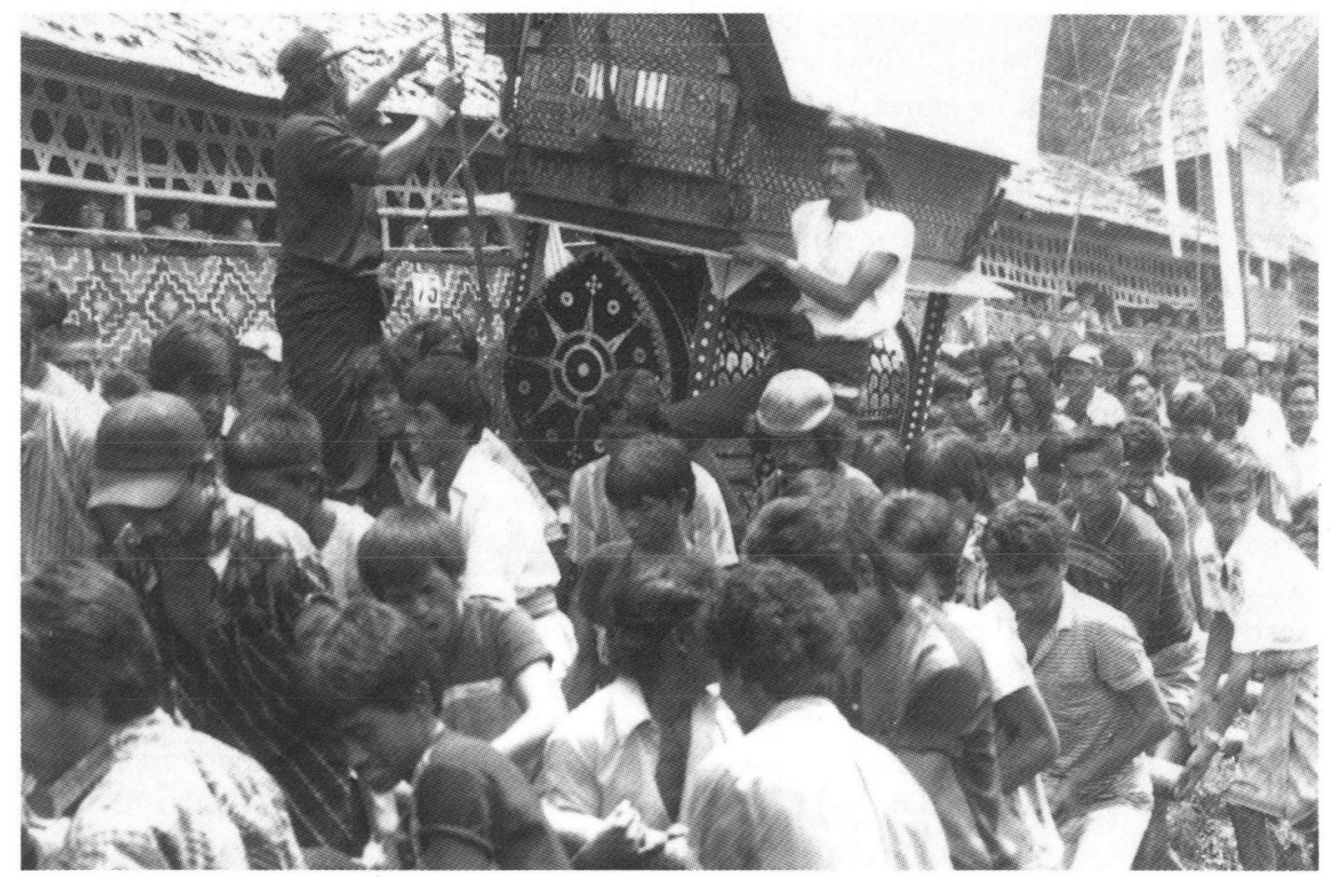

Plate 3. As guests watch from their pavilions, Ne'Ke'te's casket is carried to the ritual arena in the ma'palao procession.

sequence of compressed events, events scheduled by the clock and narrated by the ever-present voice of protocol. There was one narrative, one voice, one stream of action to which everyone's attention was directed. The novelty of protocol's monologue is perhaps best appreciated when contrasted with the role of speech in aluk ritual, particularly tominaa [priestly] speech. Traditionally, the tominaa alone possessed the power to communicate with the spirit world through esoteric high speech, and at any ritual he would do so at great length ... Although his gift of speech was highly valued, it was also rather casually disregarded. As he chanted, other people would fall asleep or go about their own business. (Volkman 1990:106)

In short, Torajans' growing discourse with the wider world has not only emphasized the entertainment value of funerals, but has brought a devaluation of the spirit audience. It seems the tourists jesting that Tana Toraja is not Club Med but Club Dead are not so far off the mark. Like Club Med, contemporary Torajan funeral rituals involve a steady stream of entertainment and a preoccupation with satisfying the guests.

\section{Conclusion}

For Torajans today, marking death has become more than a religious and practical event. It has become an endeavour that requires self-conscious staging and extensive 
choreography. This is not to say that aesthetic considerations and staging were absent 50 or even 100 years ago. Anyone viewing the ornately carved coffins dating back to this period or recalling Harry Wilcox's discussion of the carefully-planned staggering of guest entourages at funerals in the 1940s would know that Torajans have long been attentive to aesthetics and staging at their larger funerals. However, at contemporary large-scale Torajan mortuary rituals such as $\mathrm{Ne}^{\prime} \mathrm{Ke}^{\prime} \mathrm{te}^{\prime} \mathrm{s}$, these things have taken on even more importance (in proportion to other aspects of the funeral) than in the past. In fact, aesthetics and staging now appear to be central to Torajans' reconceptualization of what constitutes a successful funeral. Whereas in the past, a successful funeral was one which moved the spirit of the ancestor from this world to the next, today new criterion have been added as a result of Torajans' discourse with the wider world. In the 1990s, Torajans organize their funerals much as the government and church organize their activities, with carefully-constructed committees. A successful largescale funeral is one which flows as smoothly as a television variety show, with aesthetic sparkle and no lag in events or guest entertainment. And finally, a successful funeral is one which not only attracts guests from afar, but which receives layers of literary and video documentation. In short, outward migration to urban centres, increased familiarity with the bureaucratic structures of the government and church, exposure to the mass media, and the presence of tourists and anthropologists have all fuelled Torajans' reformulation of their traditional mortuary complex. Today's Torajan funeral ritual is a product of this dialogue with the wider world.

\section{Notes}

1 Likewise, it is to the Dutch linguist and missionary $H$. van der Veen that we owe the first transcription of the Torajan chant for the deceased (1966).

2 As far as I can ascertain, both the 1948 funeral described by Wilcox and the 1989 one I will be discussing were for men of comparable rank. Unfortunately, I am unable to ascertain the locale of the funeral for Palinggi's father, although I suspect that it was in the village adjacent to the one I will be discussing, as this was Palinggi's residence when Wilcox came to know him.

3 A pseudonym.

4 Not all of these guests would overnight at the site of the ritual - many had made arrangements to stay in hotels or with relatives in other villages. The tourists, for the most part, would attend the ritual for an hour or two over the course of one or two days.

5 According to one Torajan informant, the trend towards committee organization at funeral rituals first began in the 1970s, when Torajans who had migrated to Jakarta and Ujung Pandang began returning to the homeland for ritual events (Stanislaus Sandarupa, personal communication, 22 July, 1993).

6 Ironically these shirts (which are rapidly supplanting traditional woven Torajan tops and shorts as male funeral-wear) are not made locally, for there is no batik industry in Tana Toraja. Rather, they are commissioned from Javanese batik-makers in Jakarta. Even in funeral wear, then, we see traces of a pan-Indonesian dialogue. Torajans have appropriated a Javanese textile tradition (batik) and a western shirt style for their funeral ritual "uniform".

7 Some Torajans use the term "protocol" to describe this role, although at $\mathrm{Ne}^{\prime} \mathrm{Ke}^{\prime}$ te's funeral "emcee" was the term of choice. 


\section{References}

Adams, Kathleen M.

1984 "Come to Tana Toraja, 'Land of the Heavenly Kings': Travel Agents as Brokers in Ethnicity". Tourism and Ethnicity, a special issue of Annals of Tourism Research 11(3):469-485.

1988 Carving a New Identity: Ethnic and Artistic Change in Tana Toraja (Indonesia). Ph.D. dissertation, University of Washington.

1993 "The Discourse of Souls in Tana Toraja (Indonesia): Indigenous Notions and Christian Conceptions". Ethnology 32(10):55-68.

in press "Taming Traditions: Torajan Ethnic Imagery in the Age of Tourism". In E. Crystal and R. Reed (eds.), Traders, Travelers and Tourists in Southeast Asia, Berkeley: Center for Southeast Asian Studies.

Anonymous

1985 "Bapak K. Toding in Memorium". Jakarta: P.T. Dian Wacana Karya. Author's files.

1987 "Ibadah Dalam Ranka Pemakaman Ambe'ne'Reba". Unpublished manuscript. Author's files.

Atkinson, Jane

1983 "Religions in Dialogue: The Construction of an Indonesian Minority Religion". American Ethnologist, 10(4):684-696.

Belksma, J.

1922 "Lijkbezorging bij de sa'dan-Toraja in Rante Pao, inzonderheid in het district Pangala". Alle den Volcke (Maandblad van de Gereformeerde Zendingsbond). 16:42, 53,64 .

1923 "Een Zondagmorgen (een doodenfeest te Kande Api". Alle den Volcke (Maandblad van de Gereformeerde Zendingsbond). 17:29.

Bigalke, $\mathrm{T}$.

1981 A Social History of "Tana Toraja" 1870-1965. Ph.D. dissertation, University of Wisconsin-Madison.

Crystal, Eric

1970 "Toraja Town". Ph.D. dissertation, University of California, Berkeley.

1974 "Cooking Pot Politics". Indonesia 18:118-151.

1977 "Tourism in Toraja (Sulawesi, Indonesia)". In V. Smith (ed.), Hosts and Guests. Philadelphia: University of Pennsylvania Press.

Geertz, Clifford

1964 "Internal Conversion in Contemporary Bali". In J. Bastin and R. Roolvink (eds.), Malayan and Indonesian Studies Presented to Sir Richard Winstedt, pp. 282-302.

Oxford: Oxford University Press. (Reprinted in The Interpretation of Cultures.)

Groer, Anne

1991 "Intriguing Indonesia: From Temples to Tombs. Lavish Burial Sites and Lengthy Celebrations Mark a Lively Cult of Death in Remote Tana Toraja". Orlando Sentinel, Sunday Travel Section, pp H1, 17 February 1991.

Hoskins, Janet

1987 "Entering the Bitter House: Spirit Worship and Conversion in West Sumba". In R. Kipp and S. Rodgers (eds.), Indonesian Religions in Transition. Tucson: University of Arizona Press.

Kantor Statistik

1983 Tana Toraja Dalam Angkat. Makale, Indonesia.

Kipp, Rita and Rodgers, Susan

1987 Indonesian Religions in Transition. Tucson: University of Arizona Press. 
Leach, E.R.

1954 Political Systems of Highland Burma: A Study of Kachin Social Structure. Boston: Beacon Press.

Nooy-Palm, C.H.M.

1979 The Sa'dan Toraja: A Study of their Social Life and Religion. Vol. I: Organization, Symbols and Beliefs. The Hague: Martinus Nijhoff.

1986 The Sa'dan Toraja: A Study of their Social Life and Religion. Vol II: Rituals of the East and West. Dordrecht-Holland and Cinnaminson-USA: Foris Publications.

Spillane, James J.

1987 Parawisata Indonesia: Sejarah dan Prospeknya. Yogyakarta: Kanisius.

Tsing, Anna

1987 "A Rhetoric of Centers in a Religion of the Periphery". In R. Kipp and S. Rodgers (eds.), Indonesian Religions in Transition. Tucson: University of Arizona Press.

Veen, H. van der

1966 "The Sa'dan Toraja Chant for the Deceased". 's-Gravenhage: Martinus Nijhoff.

Volkman, Toby

1990 Visions and Revisions: Toraja Culture and the Tourist Gaze. American Ethnologist, 17(1):91-110.

Wilcox, Harry

1949 White Stranger: Six Months in the Celebes. London: Collins. 